\title{
AN ANALYSIS OF FIGURATIVE LANGUAGE USED IN POEM OF THE ECHOING GREEN BY WILLIAM BLAKE
}

\author{
Muji Endah Palupi ${ }^{1}$ \\ Universitas Bina Sarana Informatika \\ muji.mji@bsi.ac.id
}

Palupi, M.E. (2021). An analysis of figurative language used in poem of the Echoing Green by William Blake Journal of English Language and literature, 6(2), 9-20. doi: 10.37110/jell.v6i2.131

Received: 15-07-2021

Accepted: $28-08-2021$

Published:03-09-2021

\begin{abstract}
The purpose of this research is to study an analysis of figurative language in poetry. People are interested in reading literary books because reading literary books makes them to understand about life, human and nature. Reading literary books can get pleasure. The language used in poetry make more complex. Figurative language can make create interesting poetry. It is important to know the meaning of poems. Sometimes people read poetry without understanding the meaning conveyed. Poetry is a collection of words that express emotions or ideas into a literary text. In poetry there are many elements of language. English poetry can help students to improve their vocabulary skills. Poetry improves skills in listening word for word conveyed from the reader of the poem. Poetry analysis examines the elements of language to understand literary works as a whole. Analyzing a poem line by line allows you to learn about its structure, form, language, metric patterns, and themes. Hopefully this research can be widely accepted so that readers will be interested in knowing more about poetry and it is nuances.
\end{abstract}

Keywords: Figurative Language, Poem, Analyze Poem

\section{INTRODUCTION}

Some People interested in reading a literary book because reading a literary book is just an entertainment for them. They need relax time after they are confronted by monotonous and activities like working or studying. Reading literary book make they can get pleasure. The other reason is reading literary book makes Feeling to understanding life, human and nature. Literary book such as drama, poetry, and fiction is an author imagination of world, life, and experience remarked in words. The one of literary books. Poetry or poems. Poetic diction is different from daily expressions have straight cleared meaning and literal purposes.
According to Laurence Perrine that the meaning is one to one correspondence between word and meaning. In literary work, especially poetry form, a poet will find difficulty to bring message if he merely uses denotative meaning.

Poem expresses the idea in line by using diction, figure of speech, imaginary, rhythm, and sound and meaning pattern. Tone as elements of poem. The language used in poem is more complex. The meaning offered is not as clear as meaning of prose. There are a lot of things that can be discussed in a poem, but the writer here analyze concentrated only on the analysis of the figurative language used in the poem. Some difficulties to say the right sentences to apprehend because most of poems usually use figurative languages. The limits of

${ }^{1}$ Corresponding Author 
language by using this license to communicate. It gives the poet the chance to twist or wrest language.

Appealing to the imagination, figurative language provides new ways of looking at the new world. It always makes the use of a comparison between different things. Perrine says, poems at least have two levels of meaning.

Literal language causes poetry become makes Interesting, fresh particularly clear description of imagination. The information of language sometimes is not enough to say about certain object of poems. The poet's ways of explaining including some elements like as Metaphor, Simile, Personification, Metonymy, Apostrophe, Paradox, Stanza, Hyperbole, Irony, Assonance, Symbol, Allegory, Synecdoche, Sonnet and to make his language forceful.

Figurative language poem can create of poem concrete, condensed and interesting. It is considered as an important this to know what actually the meanings are containing within the poems. It was useless if just read the poems without understanding what actually the poems wants to convey to the readers. That is why we need to analyze imagery and figurative language more deeply. The writer took William Blake poem in figurative language because it made the writer interested in knowing knowledge of poetry and its elements in order to be more clearly understood by the writer and the reader generally.

According to Sayakhari use of figurative speech, archaism, rhyme, strange syntax. Poem often has difficult word to understand because sometimes an author used implicit sentences, feeling are dealing literature has been widely in EFL in English speaking and non-English speaking. It has been one of effective ways to develop the learner's English skill. Literature helps students to see diversity of language. Therefore, that students can develop their vocabulary explore to understand the meaning while reading literary text. It also helps students to develop their ideas to see how foreign learners literature and how they appreciate it in their learning process. In literary education. It is poetry that has a particularly difficult position it often needs quietness, silence and darkness be able to give right impression and effectiveness. Poetry has traditionally been considered 'high' art, which is only accessible to elites who are only able to understand.

Poem is a collection of words express emotions or ideas into a literary text. It helps students to increase not only language skills but also their vocabulary. Poem contains vocabulary features aids students to improve listening skill while listening to the speaker who perform poetry reading on stage video or audio.

In addition poem will drill student's reading ability through comprehending it is meaning and at the further stage their speaking skills will also improve through delivering their ideas to other students concerning to the meaning, moral value wrapped in poem.

According to Ogunsiji, 2000, the purpose of figurative language is to capture readers' interest and to deliver the idea and imagination in more entertaining way. It will present a lot of rich in meaning. Figurative language does not only decorate poems and endow them with aesthetic value, they also convey connotative meanings and produce certain special effects, which enrich the texts and make their meanings more precise and concrete.

The first poem (Echoing Green) can be Portrayed as the cycle of life. It starts with the birth in spring of the little children and then goes on to the middle age with the older people and the middle of the day. The last stanza then moves it into the last section of life- death. As the "sun goes down on the green" this can be interpreted as being the life finally coming to rest. And we choose the second poems because this poem is so interesting to analyze because of its very motivating content for all of us. Someone who has such a big dream, runs various ways to make his dream come true. Putting aside the scorn of those who think their dreams are nothing and also the writer chooses both poems because in that poems contain some of figurative language that the writer looking for, such as; personification, simile, paradox, metaphor, hyperbole.

This research discusses about analyze of figurative language in the poem therefore decided to describe based on the background in the hope that readers will be interested in knowing more about poem and nuances. In the research that will be questions are: (1). what kinds of figurative 
Journal of English Language and literature

Volume 6, Issue 2, September 2021

languages are used in William Blake poem? (2). what are the meanings of figurative languages used in William Blake poem?

\section{LITERATURE REVIEW}

\section{Definition of Figurative Language}

Figurative Language is figure of speech uses words expression with is different from literal interpretation. Figurative Language of speech is imagination of speech has more meaning.

According to Werren and Martin (in Amriani: 2009) that" Figure of Speech is a departure from ordinary form the expression or the ordinary course of idea in order to produce a greater effect ". Figurative language is used to describe an object, person, or situation by comparing it with something else.

According to Merriam Webster's Encyclopedia of Literature that figurative language or figure of speech can be classified in five major categories, there are:

a. Figures of resemblance on relationship (simile, metaphor, kenning, conceit, parallelism, personification, metonymy, synecdoche, and euphemism);

b. Figures of emphasis or understatement (hyperbole, litotes, rhetoric question, antithesis, climax, bathos, paradox, oxymoron, and irony)

c. Figures of sound (alliteration, repetition, anaphora, and onomatopoeia);

d. Verbal games and gymnastics (pun and anagram);

e. Errors (malapropism, periphrasis, and spoonerism).

According to Perrine (in Arp, 2010: 73), figurative language is figure of speech that cannot be taken literally. Figurative language is used to create a special effect or feeling. It is characterized by figures of speech language that compares, exaggerates means something other than what it first appears to mean. Perrine said that figurative language is broadly defined as any way of saying something other than ordinary way. It is more narrowly definable as a way of saying one thing and meaning another.

According to Rozakis that "figurative language saying one thing in terms of another". It means that figurative language is expression used
p-ISSN 2540-8216, e-ISSN 2654-3745

https://journal.stibaiec-jakarta/ojs/index.php/jell

by person or the author indirectly by using the comparison. It cannot be interpreted literally because the comparison in figurative language expression has the meaning.

According to Abrams that "Figurative language is a deviation from what speakers of a language apprehend as the ordinary or standard.

Significance or sequence of words, in order to achieve some special meaning or effect. By this explanation, it can be this expression is different from language that we use in daily activity. The deviation of language has occurred in figurative language. This figurative language is often used

As technique to tell the story by the author. It is used to obtain effect containing the meaning behind figurative language in which the use of it makes the description of the short story more powerful than the daily use of language or it is called literal language. When an author uses figurative language to describe the poem usually tricks language because to create implied meaning that will make readers. Think deeply about the meaning of poem. In interpreting the expression of figurative language that the reader of figurative language, the reader will use the power of imagination to imagine this expression and think what the meaning behind it. The use of figurative language creates the literary works to have high art value. This style of language makes the language more interesting and poetic.

According to Tajali (in Fadaee), he stated that figurative language has the purpose in three elements as he mentioned The language that uses figures of speech is called figurative language and its purpose is to serve three elements of clarity and beauty in the language. The aim of figurative language is to give the clarity because it explains about the comparison of the different things which has meaning behind its expression. Furthermore comparison used by the author in the short story better of work to be read by the reader. It shows the ability and the creativity of the author in using language. In addition, it also proves that the use of figurative language has made language more colorful, rich, and aesthetic. Some linguists have different perceptions to divide the kinds of figurative language. 


\section{Types of Figurative Language}

There are many types of figurative language such as symbol, simile, personification, metaphor, hyperbole, litotes, metonymy, alliteration, allusions, paradox etc. but in this research the researcher uses types of figurative language to be analyzed.

According to Gorys Keraf kinds of figurative language are:

1) Simile

An expression in which something is compared to something by the use of a function word, such as like or as. A smile is a direct comparison between things which are not similar in their essence particular.

Examples:

a. Tom eats like a horse

b. My girlfriend is like a doll

c. Emma is good as gold

2) Metaphor Analogy to distinguish two things directly in a brief form. It is similar to simile, but does not use like or as.

Examples:

a. His words stabbed at her heart

b. Life is a hungry animal

c. The teacher is hero without badge

This compares your brother to the nastiest little creature you can think of. In this case you would be making a metaphor, a form of comparison that directly compares two unlike things.

3) Personification

Describes things alive or having humanity characteristic. It shows an analogy to draw a thing as if human characteristic, or these thing, animal, and abstract term is made as human.

Examples:

a. this ship is taking me far away

b. The wind stood and gave a shout

c. The sky looks angry

4) Epithet

Clarifies a specific characteristic of someone or something. This explanation is a descriptive phrases that replacing someone or something.

Example: King of the jungle for a Tiger.

5) Synecdoche a. Syneckdochestha means receive collective. There are two types of synecdoche, synecdoche pars prototo and synecdoche totum pro parte. Synecdoche pars prototo is a figurative language that using parts of something to state whole of the parts.

Example:

The room has several glasses

(Glasses is a pars prototo name for

Something that consists of more

Than just two pieces of glass).

b. Synecdoche totem pro parte is a figurative language that using whole of the parts of something to state the parts.

Example:

Malaysia hits Indonesia 3-1 on the

final leg1 of AFF Cup competition.

6) Metonymy

This terminology comes from Greece, Meta that means showing a change and onoma that means name so, metonymy is a figure of speech that using a certain word to explain other word because has a closing relationship. Metonymy consists of the use of the name of one object or concept for another to which it is related.

Examples:

a. He buys a new Chevrolet

b. He drinks two glass of water

7) Irony

Irony comes from ironic that means deception or pretending. As the one of figurative language, irony is a certain reference to tell or say something with a different meaning or not in a literal meaning

Examples:

a. Come to my little hut

b. He is very diligent till he does not pass the test

c. You are very slim (whereas the fact is she/he is very fat)

\section{8) Apophasis}

The writer insists something but looking disclaims. The writer pretends to protect something, showing in fact.

\section{Example}

I don't want to reveal on this forum.

that you've been obscuring a

Hundred million rupiahs from the 
tax of this country

9) Apostrophe

The audience into someone who absences on the speech. Apostrophe is a figure of speech which is someone absent or dead or something. Non-human is addressed as if it were alive and present. Take something like a star poem begins.

Example:

Is this a dagger, which I see before me?

10) Alliteration

The repetitions of equal consonants. It's usually use in a poetry.

Examples:

Sit on the bed alone, staring a phone

She sells seashells by the seashore.

11) Assonance

The repetitions of equal vocals. It is use full for give stress effect just making a beauty poetry.

Example:

The people who care, if I live or die.

According to McArthur kinds of figurative language are:

1) Antithesis

A construction in which word are opposed but balanced in opposition

Examples:

a. God and beast

b. Ignorance and reason

\section{2) Euphemism}

Expression that take place of one that is taboo, negative, offensive, or too directs

Examples:

a. Sleep with that means having sex

b. Pass water that means urinate

The other kinds of figurative language are:

3) Paradox

The recall contradiction with the facts that exist

It is a statement that appears to be self-contradictory

but which may include a Latent truth. A paradox involves contradictory yet interrelated elements exists simultaneously Example: The stars danced around the night sky.

4) Hyperbole
Statement express strong feelings. Hyperbole uses an over Statement, usually deliberate and not meant to be taken literally. So hyperbole is used to emphasis a statement to produce a very dramatic effect.

\section{Examples:}

Let's have dinner, I am starving when she was in Japan, she spent ton of money

\section{5) Symbol}

Literary device that contains several layers of meaning, often concealed at first sight and its representative of several other aspects, concepts or traits than those that are visible in the literal translation alone. Symbol is using an object or action that means something more than its literal meaning. Usually symbol is a name or a picture that may be familiar in daily life.

\section{Examples:}

a. the dove is symbol of peace

b. Black is symbol represents evil or death c. He was disappointed when the mirror broke (Broken mirror is a symbol of separation)

6) Sonnet

A sonnet is a person generally structured in the form of 14 lines, usually iambic pentameter that expresses a thought or ide and utilizes an established rhyme scheme. As a poetic form, the sonnet was developed by an early thirteenth century Italian poet, Giacomo da Lentini however, it was the Renaissance Italian poet Petrarch that perfected and made this poetic literary device famous. Sonnets were adapted by Elizabeth English poets, and William Shakespeare in particular. Occitan phase sonnet meaning "little song"

Common Examples of Sonnet on poetry Themes like all poetry, sonnets can be many subject.

However, there are certain traditional subject matters that are associated with this poetic form. Some common examples of sonnet themes are:
a. Love
b. Romance
c. Beauty
d. Loss
e. Death
f. Nature
g. Religion
h. Pain 

i. God
j. suffering
k. Affection
1. Lust
m Ideal woman
n. Unattainable
o. Fulfillment

According to Wren and Martin (1981:491) state, in hyperbole a statement is made emphatic by overstatement. Hyperbole is kind of figurative language that is used to make the object become bigger than real object so it will give special effect and make the reader more imagine to understand the actual meaning from the sentences include hyperbole some of literary Work. Style of figurative language figure of speech was formed based on comparisons or similarities.

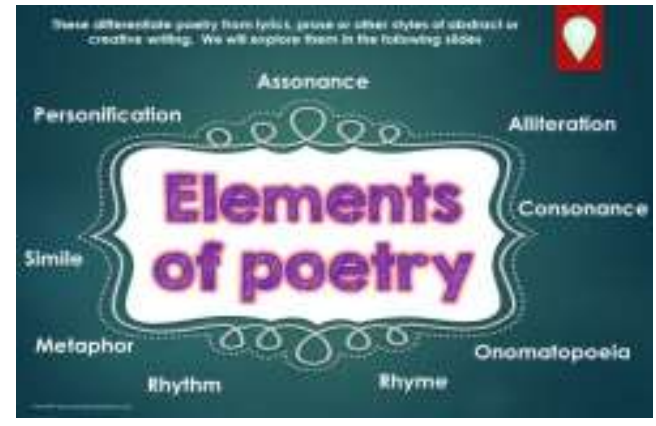

Elements Poetry of Figurative Language

According to Wren and Martin (1981:491) state, in hyperbole a statement is made emphatic by overstatement. Hyperbole is kind of figurative language that is used to make the object become bigger than real object so it will give special effect and make the reader more imagine to understand the actual meaning from the sentences include hyperbole some of literary Work. Style of figurative language figure of speech was formed based on comparisons or similarities.

\section{Poems or Poetry}

We often perceived these poems to possess a hidden meaning we're meant to decipher on our own. It's not unusual for people to consider its complexity as hindrance, as language used in poetry is usually indirect. But poetry is precise
Reflection of our experiences in life, from everything we think to the things we do. In simple terms, poetry is a form of literature that follows a flow of rhythmic lines. It uses descriptive language that offers readers an emotional insight on a given subject. Poets play around with words and sound to create a written masterpiece that reflects their thoughts and emotions. While there are various approaches to poetry, none of them require an extensive process of analysis to understand what the poem really means.

According to Robert Frost Poetry and poem describe a wide variety of spoken and written forms, styles, and patterns, and also a wide variety of subjects. Because of variety it is not possible to make a single, comprehensive definition. The poem is arranged in lines, but does not follow measured rhythmical patterns, nor does it rhyme. The most important thing about it is that, as it engages us and amuses us, it also rings of truth. Poetry is the kind of things poets writes to define poetry is not easy because not everything can be named or explained. So it is enough to sharpen your perception as a reader and to permit a fuller understanding of what it is in a poem that gives pleasure and creates form and meaning.

Siswantoro said that Poetry is the most condensed and concentrated form of literature, saying most in fewest number of words. The writer always extended their idea and will be continued to expand their imagination because they do not satisfy what they have got. Poetry is perhaps the most difficult kind of language. Poem is the most complicated literary because of its compact in condensed diction in Expressing ideas.

\section{The Elements of Poetry}

According to Kennedy and Gioia, there are several elements in a poetry. They are tone, form, language, and sound

a. Tone

Tone in literature often conveys an attitude toward person addressed. In poetry, it indicates how the speaker feels about himself/herself.

b. Form

Form is the design of a poetry configuration of all its parts. Moreover, the parts of form are; rhythm, meter, scansion, and stanza. 
Rhythm is Recurrence of stresses and pauses in a poem. Stress is a greater amount of force given to one syllable in seeking than is given to another. Rhythm is music made by statement of poem, which included the syllables in the line.

\section{c. Language}

Poetry usually uses special and unique language that makes it more beautiful and meaningful. Thus, language of poetry is divided into three kinds, they are imagery, diction, and figurative language.

\section{d. Sound}

For readers, the sound of words have a magical Spell, most powerful when it points to meaning. Furthermore, there are four parts of sound; they are onomatopoeia, alliteration, assonance, and rhyme (rime)

\section{Voice: Speaker and Tone}

Voice is the media to convey the poem's tone; its implied attitude toward its subject. Tone is an abstraction we make from the details of a poem's language; from particular choices of words and sentence patterns.

When we listen to a poem's language and hear the voice of its speaker, we catch its tone feeling and ultimately it's meaning. The voice conveys the poem's tone; it voice conveys the poem's tone; its Implied attitude toward its subject.

a. Voice: the term used to designate the creating, ordering artistic intelligence that we recognize behind any narrating persona, even an "objective" third-person one.

b. Speaker: the persona designed within the poem; the voice we hear in the poem.

c. Tone: The writer's or speaker's attitude toward his subject, his audience, or himself; the emotional coloring, or emotional meaning, of a work.

d. Voice can be referred to a writer's attitude towards his subject or readers. Tone can be termed as that reflects the mood of a writer. A writer can have different tones while raising his voice.

\section{Elements of Poetry another}

a. Imagery

Figurative language evokes as a kind mental image of the five senses, we call this imagery. She is the sun (a simile) suggests imagery of light and warmth thus she is likened compared to the sun in a positive ways though the imagery. The sun suggests life giving as well the idea of being a Centre to things that revolve around it. As mentioned above, figurative language condenses and expands meaning. In the short sentence she is the sun, much is suggested by the comparison: for the speaker of the words, she is or perhaps represents the values or powers of light-giving, life-giving, warmth, and some kind of steady center.

b. Allusion

Poetry sometimes contains brief references to things outside itself a person, a place, another piece of writing that expand, clarify, or complicate its meaning. Sometimes they are obvious and direct, and sometimes they are subtle, indirect, and debatable. Allusions are frequently references made to other texts.

\section{c. Rhyme}

Rhyme refers to the repetition of sounds in a poem. Various types of rhyme are possible, however in English we usually use the term rhyme to refer to repetition of the final sounds in a line. Letters are often used to denote a rhyme scheme. A new letter is ascribed to each of different sounds.

Example:

The people along the sand

All turn and look one way.

They turn their back on the land.

They look

\section{d. Alliteration}

This device involves the repetition of the initial consonant sound of a series of words, often consecutively. Alliteration is most easily explained to students through looking at a few simple tongue twisters, such as Peter Piper or She Sells Seashells.

Example:

Betty Botter bought a bit of butter

But, the bit of butter Betty Botter bought was bitter So Betty Botter bought a better bit of butter

e. Stanza 
The lines form the basic metrical unit in a poem. In a 12-line poem, the first four lines might be a stanza. You can identify a stanza by the number of lines it has and its rhyme scheme or pattern, such as A-BA-B. There are many different types of stanzas.

\section{Examples:}

Hey Jude, do not make it bad

Take a sad song and make it better

Remember to let her into your heart

That you can start to make it better

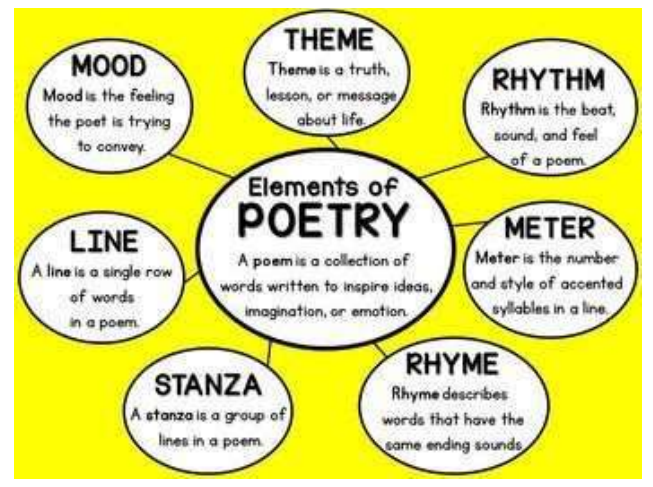

Elements of Poetry

\section{Poetry analysis}

The process of investigating a poem's form, content, structural semiotics and history in an informed way, with the aim of heightening one's own and others' understanding and appreciation of the work. The words poem or poetry derive from word from the Greek poiéma (to make) and poieo (to create). That is, a poem is make thing a creation; an artifact. One might think of a poem as.

According to William Carlos a machine made of words. Machines produce some effect, or do some work. They do whatever they are designed to do. The work done by this "machine made of words" is the effect it produces in the reader's mind. A reader analyzing a poem is akin to a mechanic taking apart a machine in order to figure out how it works. Like poetry itself, poetry analysis can take many forms, and be undertaken for many different reasons. A teacher might analyze a poem in order to gain a more conscious understanding of how the poem achieves its effects, in order to communicate this to his or her students. A writer learning craft of poetry might use the tools of poetry analyze to expand and strengthen his or her own mastery. A reader might use the tools and techniques of poetry analysis in order to discern all that the work has to offer, and thereby gain a fuller, more rewarding appreciation of the poem

\section{How to Analyze Poetry?}

Poetry analyze is examining the independent elements of a poem to understand the literary work in it is entirety. Analyzing poems line by line allows you to break poems down in order to study their structure, form, language, metrical pattern, and theme.

The purpose of literary analyzing is to interpret the meaning of poem and appreciate it on a deeper level.

a. Read the poem. The first time you approach. a poem, read it to yourself. Go through it slowly, appreciating the nuances and details you might miss when reading it quickly. Examine the title of the poem and how it relates to the meaning of the piece.

b. Read the poem again, this time aloud given its rhythmic patterns, poetry is designed to be read aloud. As you read a poem aloud, listen to how the words and syllables shape the rhythm. It can also help to hear someone else read the poem. Look online and find a recording of the poem, if you can. Listen to how the words flow from line to line, where the breaks are, and where the stress is placed.

c. Map out the rhyme scheme. You will notice right away if a poem has a rhyme scheme or is written in free verse. Map out The rhyming pattern by assigning each line a letter, giving lines rhyme same letter. See if there is a distinct pattern and a formal rhyme scheme, (three-line stanzas with interconnected scheme of ABA BCB)

d. Scan the poem. Scansion is analyze meter of poetry based on the pattern of stressed and unstressed syllables in each line. Mark each foot basic measurement of poetic line consisting of one stressed syllable paired with at least one unstressed syllable.

e. Break down the structure. Take a step back and look at the poem on the page. Notice the white space around the words. Poetry is meant to make a visual statement as well as an emotional one. Look at the details of this structure like how many lines are in each stanza. 
f. Determine the form of the poem. In your poem analysis, note what type of poem you're reading based on the elements you've examined. If a poem has three quatrains followed by a couplet poem is a sonnet other formal types of poetry include sestina, haiku, and limerick.

g. Study the language in the poem. Poets make deliberate word choices to craft their poems. Examine each word and its significance in the line and the poem.

h. Study the content of the poem. Look at content and message of the piece to uncover the theme. Learn when it was written to learn historical context of poem. Find out where it was written, and what language the poet used. If you're reading a translation, see if there are other variations that can show how different translators interpreted the original work.

i. Determine who the narrator is. Try to identify the speaker of the poem. The speaker's identity influences the telling of the poem based on their personal perspective.

j. Paraphrase the poem line by line. Beginning the first line paraphrase each line. In other words, interpret the meaning, writing down your summary as you go. Once you've gone through the entire piece, read your words to grasp the meaning of the poem.

\section{METHOD}

This research discusses about Analyze of Figurative Language Used in The Poem.

\section{The Echoing Green by William Blake}

The sun does arise and make happy the skies. The merry bells ring to welcome the spring. The sky-lark and thrush the birds of the bush, sing louder around, to the bells' cheerful sound while our sports shall be seen On the Echoing Green.

Old John, with white hair does laugh away care, sitting under the oak, among the old folk, they laugh at our play and soon they all say. 'Such, such were the joys. When we all girls \& boys in our youth-time were seen On the Echoing Green.

Till the little ones weary No more can be merry the sun does descend, and our sports have an end; Round the laps of their mothers Many sisters and brothers, Like birds in their nest,
Are ready for rest; And sport no more seen On the darkening Green.

\section{Analyze of Poem The Echoing Green by William Blake}

The echoing Green by William Blake is a three stanza poem that embodies an AABBCCDEF rhyme scheme. Through it is course to present a theme that is as beautiful as it is melancholy. The beauty comes in the form of life enjoyment that is showcased through the children playing in the fields as a character, "Old John" watches, but the melancholy is subtly dealt with in the guise of an undertone of how fleeting youthful zeal can be, furthermore, Blake uses that simple vision of play or lack thereof that is occurring on "The Echoing Green" to symbolize the passing quality of life in general.

\section{First Stanza}

The sun does arise, and make happy the skies. The merry bells ring to welcome the Spring.

The sky-lark and thrush,

The birds of the bush,

Sing louder around,

To the bells' cheerful sound.

While our sports shall be seen

On the Echoing Green.

Wastes no time in delivering the brightness that is occurring on this "Echoing Green" though no specific person is initially addressed as a part of the scenery rather, Blake concentrate on the sounds and scenes that nature and inanimate objects bring to give a background of merriment before people are added to the equation. Specially, "the sun in "happy .... skies" while "merry bells ring" and "birds" offer their own "cheerful" sounds, before we ever come across a single person in this poem, we are grounded in scenery that exemplifies. The final two lines though, we realize that the narrator is a part of some group playing "sports" among the happy sounds on "Green" land. From the animals and inanimate objects to the joy and plant life, this scenery is treated like a thing of beauty, and the concept is so childish playing in a field that the reader can conclude that this group is made up of children. Under the weight of this deduction the whole stanza shifts in meaning to something much deeper than just children playing. The lively qualities and happiness expressed are 
representations of the vivacity of youth where life is still as early and fresh as a "sun" that's high in "happy...skies." In this state of life, People can play, run, and enjoy what's around them in a handson way.

\section{Second Stanza}

Old John, with white hair

does laugh away care, sitting under the oak,

among the old folk, they laugh at our play and soon they all say. 'Such, such were the joys. When we all girls \& boys

in our youth-time were seen

On the Echoing Green.'

We were introduced to the only character who's given a specific name, and "Old John" is of note because he's observing the merriment occurring in "the Echoing Green" even though he himself is not partaking. This can be seen as stepping into a different stage of life than the one in which the children exist as "Old John" likely can't partake in those activities due to his age. Instead of sharing in that heightened level of motion, he's "[s]itting under the oak" in the company of "the old folk" as he watches the display.

The use of "the oak" in this stanza is of particular significance in two ways. One, we get a visual of a series of older people casually assembled in the shade of a towering tree. This image is both helpful in giving the reader a mental picture of the setting and also reinforcing that elderly quality for this group. They aren't running or even walking. They're sedentary.

This leads into the second significance of "The oak" since the tree is a symbol of wisdom and steadfastness due to the time required to grow a Tree large enough for a series of people to linger beneath. By providing such a representation of older superiority and strength, Blake is commenting on the wisdom and steadfastness to be had in the elderly group who has endured decades of life experiences. Regardless of elderly quality though "Old John" Still finds happiness in the children's Antics, and the young narrator is aware of this detail as his comments things like how the observers "laugh at [the] play." But even in this child's description of the elders genuinely finding enjoyment, there's the first hint of melancholy showing itself in the latter lines of the stanza. This sad twist arises through the reminiscing of the elder generation about the times when they were all "girls \& boys" who experienced similar joys as the children's. Though the observers remember those days and can still enjoy the children's happiness, they will never again be able to experience that same free quality and activity as the children currently are. It's worth noting as well that the phrase, "girls \& boys," is evidence in favor of the idea that the people playing at "the Echoing Green" are children. If not, the recollection would lose sensibility in that no "girls \& boys" would be present to spark the comparative comment.

\section{Third Stanza}

Till the little ones weary No more can be merry the sun does descend, and our sports have an end;

Round the laps of their mothers

Many sisters and brothers,

Like birds in their nest,

Are ready for rest;

And sport no more seen

On the darkening Green

What was already a melancholy detail in the second stanza grows to overtake the remainder of the poem. Now, there's no more playing as "the sun does descend," creating a scene that's much darker and less active than what was presented in the first stanza. At first glance, this scenario could be explained as children going Home for the sake of sleep and such, but a careful exploration of the wording reveals so much more. For one thing, this is the first time the children are referred to by the narrator who claims to be a part of the group as the little ones This isn't vernacular often connected to a child by another child, so it's constructed to stick out and sparks the question of why a child would

Suddenly be referring to the youth in such a way. The most logical of explanations would be that the child is no longer a child, but rather is growing or has grown into an adult. From that viewpoint, the meaning of this final stanza alters to surround that idea. "Sports have to end" becomes a statement of having to leave behind the merriment of childhood so much that "sport [will] no more be seen." That last quote, too, affords this theory of passing into adulthood credibility since narrator doesn't mention a time when the play can recommence. By the word 
choice, it's just over as age comes and death approaches. Much like a day has a sunrise and a sunset, so does life, and this stanza clearly notes that "descend[ing]" is taking place. The vivacity of childhood is draining, and as life passes, the "Green" is no longer "Echoing." It's "darkening," like the light of life slipping away.

This theory does make description of children being "(r) round laps of their mothers / many sisters and brothers". An odd thing. If the narrow is now talking about aging adults, after all, the visual of them gathered around "the laps of their mother" fell out of place. However this statement is actually quite fitting. Let's recall that those elderly fellows were watching children play by "the oak" in stanza 2. Perhaps then "the oak" being tread like the "mothers" in this scenario or rather what "the oak" would represent. The steadfastness and wisdom that was earlier addressed could be the explanation needed here, that these former children who are now aging adults are gathered around wisdom and steadfastness garnered from life experience. This concept adds beauty even to the most melancholy of stanza in the poem. Even though they are have grown solid and strong. What begins then as purely beautiful tale in the first stanza progressively delves into melancholy until the beauty in the end has shifted from the primary focus to the underlying theme still Blake effectively created a poem to showcase both beauty and melancholy of aging and life.

\section{of Figurative Language Simile}

Many sisters and brothers,

Like birds in their nest,

It is means all human being were family, so human being should help each other like the birds that were always together.

\section{Personification}

The sun does arise and make happy the skies It means that the reader's imagination of the atmosphere of the rising sun is not only felt by humans but can be felt by the whole nature, for example, making the sky happy.

The birds of the bush sing louder around
It's means that the reader's imagination to the atmosphere of cheerfulness was felt not only by human but also by other creatures like birds. Singing louder, they welcome the spring.

\section{CONCLUTION}

Literary book such as drama, poetry, and fiction is an author imagination of world, life, and experience remarked in words. Poetry or poems. Poetic diction is different from daily expressions have straight cleared meaning and literal purposes. Figurative language poem can create of poem concrete, condensed and interesting. It is considered as an important to know the meanings are containing in the poems. Sometimes read poems without understanding what actually the poems wants to convey to the readers. That is why we need to analyze imagery and figurative language more deeply.

Poetry is a collection of words that express emotions or ideas into a literary text. Learn poetry helps Students to improve language skills and vocabulary. Poetry contains vocabulary and can help students to improve listening skills while the speaker is reading poetry on stage, listening to video or audio.

In addition, poetry trains students' reading skills through understanding it is the meaning in understanding poetry texts. Speaking skills will improve through the delivery of ideas. Students can understand the meaning, moral values in poetry. The process of forming poetry, it is content, structural semiotics and its meaning clearly, with aim of increasing understanding and appreciation of one's own work and that of others. Poetry analysis is to examine the independent elements of a poem to understand the literary work in it as a whole. Analyzing a poem line by line allows you to understand the poem to learn about its structure, form, language, metric patterns, and themes.

Analyzes the poem written by William Blake concluded that the figurative language used in the poem are metaphor, simile, personification, hyperbole and paradox. "The Echoing Green" by William Blake tell that spring is always come but it also ends. As a life, starting from childhood to adulthood and will revolve around our next offspring so do not waste our childhood. Times when playing was so much fun, growing into an 
active and creative teenager to become successful in old age.

\section{REFERENCES}

Abrams M. H, A Glossary of Literary Terms Ed. $7^{\text {th }}$ (US, Massachusetts, 1981),p.63.

Fadaee, Elaheh. 2010. Symbols, Metaphors \& Simile in Literature:A Case Study of Animal Farm. E. Journal. 2(2): 19-27 http://www. Academic journals. Org/ijell on November 4th 2016.

Kennedy, X.J and Dana Gioia. 2005. An Introduction to Poetry New York: Longman

Keraf, Gorys. 2008. Diksi Dan Gaya Bahasa. Jakarta: PT Gramedia Pustaka Utama

McArthur, Tom (ed). 1992. The Oxford. Companion to the English Language. New York: Oxford University Press

Miller, Ruth \& Robert A. Greenberg. 1981. Poetry An Introduction. Hong Kong: MacMillan Education Limited

Roberts, Edgar V \& Henry E. Jacobs. 1995. Literature. The United States of America: Prentice Hall.

Rozakis, Laurie. E. 1995. How to Interpret Poetry. New York: A Simon \& Schuster Macmillan Company

Sayakhan, Najat Ismael. 2014. The Teaching Problems of English Poetry in the English Departments.Bloomington: Author house

Siswantoro. 2002. Apresiasi Puisi-puisi Sastra Inggris.Muhammadiyah University Press Pike, M. A (2000). Boys, poetry and the Individual talent vol34 pages 41-55.

Perrine, Laurence. 1977. An Introduction to the Poetry. New York: Harcourt. Brace Javavovich
Webster, Merriam. 1995. Merriam-Webster's Encyclopedia of Literature (USA: MerriamWebster, Inc) www.literarydevices.com/repetition / On December 10th 2017

https://en.m.wikipedia.org/wiki/Literal and figura tielanguageon December 10th 2017 https://en.wikipedia.org/wiki/Poetryanalysis

https://www.masterclass.com/articles/howtoanalyze- poetry\#how-to-analyze-a-poem-in10-steps

https://corporatefinanceinstitute.com/resources/kno wledge/other/figurative-language/

https://web.uvic.ca/hrd/closereading/imagery.html

https://poemanalysis.com/william-blake/theecchoing-green/

https://en.wikipedia.org/wiki/William_Blake 